Universidad de Lima

Facultad de Derecho

Carrera de Derecho

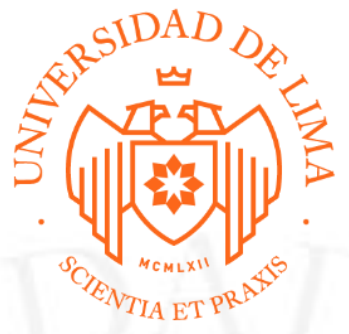

\title{
CIVIL: "RESPONSABILIDAD
} EXTRACONTRACTUAL" Y

\section{ADMINISTRATIVO: "ELIMINACIÓN DE BARRERAS BUROCRÁTICAS"}

Trabajo de suficiencia profesional para optar el Título Profesional de Abogado

Keyleen Lucero Cruz Lau

Código 20131744

Lima - Perú 


\title{
CIVIL: " RESPONSABILIDAD EXTRACONTRACTUAL"
}

Materia: Responsabilidad Extracontractual

No de Expediente: 28185-2005-0-1801-JR-CI-28

\begin{abstract}
RESUMEN
El presente caso versa sobre la presunta responsabilidad civil extracontractual, demandada por A. y A. A. S.A, contra B. S.A Ingeniería, derivada de un supuesto daño ocasionado a consecuencia de la emisión de un laudo arbitral. Este proceso fue conocido en primera instancia por el Vigésimo Octavo Juzgado Civil de Lima, en segunda instancia por la Sexta Sala Civil de la Corte Superior de Lima; y por último, en sede casatoria, por la Sala Civil Permanente de la Corte Suprema de Justicia.
\end{abstract}

\section{ADMINISTRATIVO: "ELIMINACIÓN DE BARRERAS BUROCRÁTICAS"}

Materia: Responsabilidad Extracontractual

$\mathrm{N}^{\mathrm{o}}$ de Expediente: 28185-2005-0-1801-JR-CI-28

\section{RESUMEN}

El presente caso versa sobre la presunta imposición de barreras burocráticas ilegales y carentes de razonabilidad, contenidas en los artículos primero, tercero y cuarto de la Ordenanza Municipal No 01-2009-MPCH, emitida por la Municipalidad Provincial de Chincha, la cual fue denunciada por C. C. C. S.A, ante la Comisión de Eliminación de Barreras Burocráticas, y resuelta en segunda instancia por la Sala Especializada en la Defensa de la Competencia. 